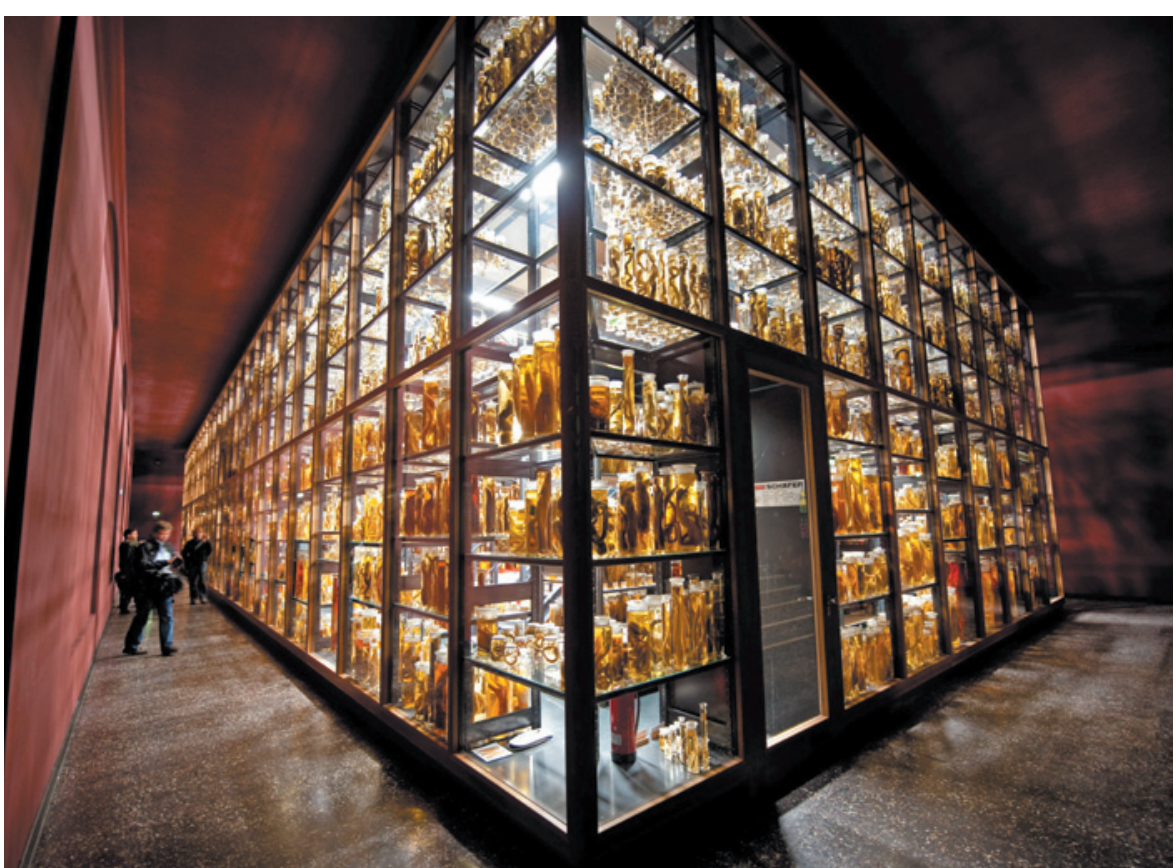

Berlin's natural history museum has exploited the aesthetic qualities of its spirit collection.

MUSEUMS

\title{
A natural evolution
}

\section{Henry Nicholls reflects on how the 'phenotypes' of natural history museums are adapting to change.}

$\mathrm{H}$ ow are the world's natural history museums faring in the twenty-first century? There can be little doubt that humanity is obsessed with nature. If you were to pile up every painting, potsherd and preserved bit of flora or fauna on show in every UK museum, for instance, around half of the artefacts would be objects of natural history. But in recent years, research practice and priorities have undergone a rapid evolution that exhibitions have struggled to reflect.

The gradual disappearance of empirebuilding aspirations, the emergence of the conservation movement and the rise of molecular biology have led to a decline in the collection of whole organisms. Fossils and minerals remain fair game, but researchers are mostly content to leave plants and animals where they are; a tissue or DNA sample is enough to keep them busy for decades. Yet it is still common for visitors to natural history museums to be confronted with lots of taxidermy and little interpretation.

Bringing front-of-house exhibitions into line with behind-the-scenes research is crucial. With climate change and loss of biodiversity a reality, and conflict over food production and water likely, natural history research is of increasing relevance. And with the global economy still troubled, museums

must engage with the public, communicate their value and justify investment.

There are several reasons why it is hard to bridge the gulf between the realities of research and public perception of natural history. It costs money and manpower, so small, resource-strapped collections tend to have more dated displays than their wealthier counterparts. And molecular analyses, theoretical models and phylogenetic reconstructions need considerable interpretation. A computer screen full of base pairs isn't as easy to 'sell' to the public as a stuffed marmoset.

Happily, the world's biggest players are taking the problem seriously. In 2001, the American Museum of Natural History $(\mathrm{AMNH})$ in New York became one of the first to tackle the molecularity of natural science with TheG enomic Revolution, a temporary exhibition launched soon after the first draft of the human genome was published. Communicating molecular findings is hard, but it can be done.

Other developments translate more easily into displays. Take the use of computed

DNATURE.COM For the evolution of conservation: go.nature.com/tchfk3 tomography (CT) scanners, which expose specimens in onceimpossible ways. Digital data offer a huge opportunity for new types of presentation.

With its Darwin Centre, London's Natural History Museum has made it possible for visitors to see directly into laboratories. The 'display' has not been universally popular with researchers, but the message is clear: there are real people here, doing real science. Most museums now also give researchers and curators plenty of chances to present their work in tours, hands-on lectures and workshops.

Rethinking natural history need not mean doing away with stuffed specimens. A museum that can achieve greater parity between labs and exhibition spaces may even find it easier to embrace - and celebrate the specimens on which it was founded. Such exhibits will be liberated, becoming objects less of natural history than of history and art. Once they acquire these new meanings, even more opportunities for public engagement will arise, and audiences will grow.

Take the Hall of North American Mammals at the AMNH, home to some of the world's most exquisite dioramas. These continue to be viable ways of conveying zoological, ecological and geological information. And the older they get, the more obvious their historical value becomes. Ongoing renovations to the gallery will see non-scientific meanings come to the fore, and will explore President Theodore Roosevelt's pioneering role in US conservation: among other things, he created five national parks and the US Forest Service.

Plenty of collections are paying more attention to the aesthetics of their specimens. The London museum was one of the first to exploit the grotesque qualities of specimens preserved in alcohol to fantastic visual effect, when it opened its spirit collection in phase 1 of the Darwin Centre in 2002. The Museum for Natural History in Berlin followed suit with its rebuilt East wing in 2010. It also boasts a stunning taxidermic 'biodiversity wall', which resembles a seventeenth-century cabinet of curiosities. And from September 2011 to January 2012, the Smithsonian Institution's National Museum for Natural History in Washington DC boasted an installation about bioluminescence by artist research fellow Shih Chieh Huang.

The nineteenth-century philosopher, poet and environmentalist Henry David Thoreau once denigrated museums as "catacombs of nature". But he never got to stand in a twentyfirst-century space looking at beautifully presented specimens with a historical narrative delivered through earphones. Given that, and the ability to scan a DNA barcode to resurrect a CT-scanned, whole-organism hologram and manipulate it with a wave of his hand, Thoreau might reconsider.

Henry Nidhollsis a sciencejournalist based in London, and the author of The Way of the Panda (ProfileBooks, 2010). e-mail: henry@henrynicholls.com 